\title{
Age and growth determination by skeletochronology in loggerhead sea turtles (Caretta caretta) from the Mediterranean Sea
}

\author{
PAOLO CASALE ${ }^{1}$, NICOLETTA CONTE ${ }^{1}$, DANIELA FREGGI ${ }^{2}$, CARLA CIONI $^{1}$ \\ and ROBERTO ARGANO ${ }^{1}$ \\ ${ }^{1}$ Department of Biology amd Biotechnologies "Charles Darwin”, University of Rome "La Sapienza”, 00185 Roma, Italy. \\ E-mail: paolo.casale@tiscali.it \\ ${ }^{2}$ Sea Turtle Rescue Centre WWF Italy, 92010 Lampedusa, Italy.
}

\begin{abstract}
SUMMARY: Skeletochronology was applied to humerus bones to assess the age and growth rates of loggerhead sea turtles (Caretta caretta) in the Mediterranean Sea. Fifty-five dead turtles with curved carapace lengths (CCL) ranging from 24 to $86.5 \mathrm{~cm}$ were collected from the central Mediterranean. Sections of humeri were histologically processed to analyze annual growth marks. Two approaches were used to estimate the somatic growth in the form of a von Bertalanffy growth function. The first approach was based on calculating the total number of growth marks, which corresponds to the age of turtles at death. The second approach estimates the carapace length at old growth marks in order to provide the growth rate of each turtle. The observed individual growth rates ranged from 1.4 to $6.2 \mathrm{~cm} \mathrm{yr}^{-1}$, and showed both elevated inter- and intra-individual variability possibly related to the environmental variability experienced by turtles during their lifetime. Both approaches gave similar results and suggest that Mediterranean loggerhead turtles take 14.9 to 28.5 years to reach a CCL of 66.5 to $84.7 \mathrm{~cm}$. This size corresponds to the average size of nesting females found in the most important Mediterranean nesting sites and can be considered the approximate size at maturity.
\end{abstract}

Keywords: loggerhead sea turtle, growth rate, age at size, skeletochronology, Mediterranean.

RESUMEN: DETERMINACIÓN DE LA EDAD Y EL CRECIMIENTO POR ESCLEROCRONOLOGía EN LA TORTUGA BOBA MARINA CARETTA CARETTA DEl MAR MediterRáneO. - La esclerocronología se aplicaba a los huesos de los húmeros para determinar la edad y las tasas de crecimiento de la tortuga boba Caretta caretta del Mediterráneo. Cincuenta y cinco tortugas bobas muertas de 24 a $86.5 \mathrm{~cm}$ de longitud de la curvatura del caparazón (CCL) fueron recogidas del Mediterráneo central. Secciones de los húmeros fueron procesados histológicamente para analizar las marcas anuales de crecimiento. Se aplicaron dos aproximaciones para determinar el crecimiento somático utilizando la función de crecimiento de von Bertalanffy. La primera aproximación se basaba en el número total de marcas de crecimiento, correspondiendo a la edad de las tortugas en el momento de la muerte. La segunda aproximación era una estimación de la longitud del caparazón en las marcas de crecimiento más antiguas, con la intención de saber la tasa de crecimiento de cada tortuga. Las tasas de crecimiento individual observadas, oscilaban entre 1.4 y $6.2 \mathrm{~cm}$ año $\mathrm{O}^{-1}$, mostrando una elevada diversidad individual intra e interanual, posiblemente ligada a la variabilidad ambiental experimentada por las tortugas bobas durante su vida. Ambas aproximaciones dieron resultados similares y sugieren que la tortuga mediterránea tarda 14.5-28.5 años en alcanzar un tamaño de 66.5-84.7 cm de CCL. Este tamaño corresponde al tamaño medio de las tortugas bobas hembras nidificantes, encontradas en la mayoría de lugares nidificantes del Mediterráneo y puede ser considerado el tamaño aproximado de la madurez.

Palabras clave: tortuga boba marina, tasa de crecimiento, edad y tamaño, esclerocronología, Mediterráneo.

\section{INTRODUCTION}

Sea turtles are threatened worldwide by many human activities, from direct exploitation to climate change (Lutcavage et al., 1997). In order to understand how the populations of these threatened species respond to human impacts and plan suitable conservation strategies, much more information on turtle population 
dynamics is needed. In this respect, assessing growth rates is fundamental in order to estimate the duration of the different life history stages as well as the age at maturity because these are key parameters in population models (e.g. Heppell et al., 2003b; Mazaris et al., 2005). This represents one of the top 20 research priorities recently identified for sea turtles (Hamann $e t$ al., 2010).

Sea turtles may show extremely variable growth rates, even within the same species, which may be caused by genetic, sexual and/or environmental factors (see Heppell et al., 2003b). For instance, Bjorndal and Bolten (1988) reported that growth rates of loggerhead turtles in the Bahamas were much higher than those of the same size class in the North Atlantic (Bjorndal et $a l ., 2000)$. For this reason, the growth rates of a certain population/area cannot necessarily be assumed to be the same for another population or area, and it is necessary to obtain specific estimates for different populations and even at different foraging grounds frequented by the same population. For instance, in the two studies mentioned above, turtles in the Bahamas may have had more access to neritic grounds than the turtles in the Atlantic.

The loggerhead sea turtle (Caretta caretta) (Linnaeus, 1758) is the most common sea turtle species in the Mediterranean, widespread all over the basin (Margaritoulis et al., 2003), and is listed as endangered in the IUCN Red List of Threatened Species. Although high numbers of Atlantic turtles enter the Mediterranean (Laurent et al., 1998; Carreras et al., 2006; Casale et al., 2008b), genetic markers indicate that the Mediterranean population is relatively isolated from the Atlantic populations (Laurent et al., 1998). One of its most distinctive characteristics is the significantly smaller adult size in comparison with other populations around the world (Dodd, 1988; Tiwari and Bjorndal, 2000; Margaritoulis et al., 2003). This may be an adaptation to particular conditions and could be due to earlier sexual maturation and/or slower growth. Considering that the number of turtles caught in fishing gear and their associated mortality are estimated to be high (Casale, 2011), it is particularly urgent to assess when turtles become mature and develop reliable population dynamics models that can help to understand the impacts of the anthropogenic threats in the basin. Estimating growth rates of sea turtles is not a simple task and several approaches have been developed (Heppell et al., 2003b). Multiple measurements of the same individual at time intervals using a capture-markrecapture (CMR) approach is the most obvious method for obtaining such data. However, turtles are so vagile and relatively slow growing that intensive and longterm CMR programs are required. A valuable approach is skelotochronology, which is based on analyzing growth marks resulting from the annual cycle of bone deposition (Zug et al., 1986). However, growth marks are not always clearly recognizable and bone resorption and remodelling require correction protocols ( $\mathrm{Zug}$ et al., 1986; Parham and Zug, 1997). A third approach is length frequency analysis, which identifies progressive cohorts by identifying size modes (Bjorndal et al., 2000). Unfortunately, this method requires a very large number of size records and is based on several assumptions (e.g. Bjorndal et al., 2000). Therefore, it is evident that the results obtained with different approaches need to be compared before an estimate obtained with a single approach can be considered reliable.

A first attempt to assess growth rates in the Mediterranean was made by using a capture-mark-recapture (CMR) approach, i.e. size data of the same individuals measured at different times. With this method the age of nesting females in the Mediterranean Sea was estimated to be 16 to 28 years (Casale et al., 2009) depending on the nesting site.

The present study provides a further estimation of growth rates and the age at maturity for Mediterranean loggerhead turtles by using a skeletochronology approach that also provides information on time-related growth rates in the same individual.

\section{MATERIALS AND METHODS}

\section{Sample collection and processing}

Skelotochronology is based on identifying growth marks on bones, assumed to be deposited according to an annual cycle. Humeri have been successfully used in sea turtles (Zug et al., 1986).

In this study, humeri were dissected during necropsies of 55 dead loggerhead turtles collected at the WWF Italy Rescue Center on Lampedusa Island (Italy). These turtles were either accidentally captured by fishing gear and brought to the centre by fishermen, or found stranded or floating at sea in an unhealthy state in the period 2001-2007 in the Sicily Channel (central Mediterranean). The curved carapace length notch-totip (CCLn-t) (Bolten, 1999) of all turtles was measured. Turtles ranged from 24 to $86.5 \mathrm{~cm}$ CCL (mean: 52.2) and were assumed to be mostly juveniles because Mediterranean loggerhead turtles mature on average at a size larger than $70 \mathrm{~cm}$ CCL (Margaritoulis et al., 2003; Casale et al., 2005), and in the Atlantic at an even larger size (ca. $100 \mathrm{~cm}$ CCL)(Dodd, 1988). Left, right or both humeri were collected from each turtle and frozen. Before further processing, defrosted bones were cleaned and boiled to remove any remaining soft tissue, then rinsed in a 1:1 bleach:water solution (Avens and Goshe, 2007), and allowed to dry outdoors for a period of 15 to 20 days. A 3-5 mm thick section was cut from the narrowest part of the diaphysis using a circular saw (Logitech). This is the optimal site for skelotochronology because the humerus here retains the greatest number of periostal growth layers (Zug et al., 1986). The bone sections were fixed in $10 \%$ buffered formalin for $24 \mathrm{hrs}$, rinsed in water and decalcified in 17\% EDTA solution (OSTEOSOFT for microscopy, Merck), $\mathrm{pH} 7-7.3$, at $37-60^{\circ} \mathrm{C}$ for 2-60 days, depending 


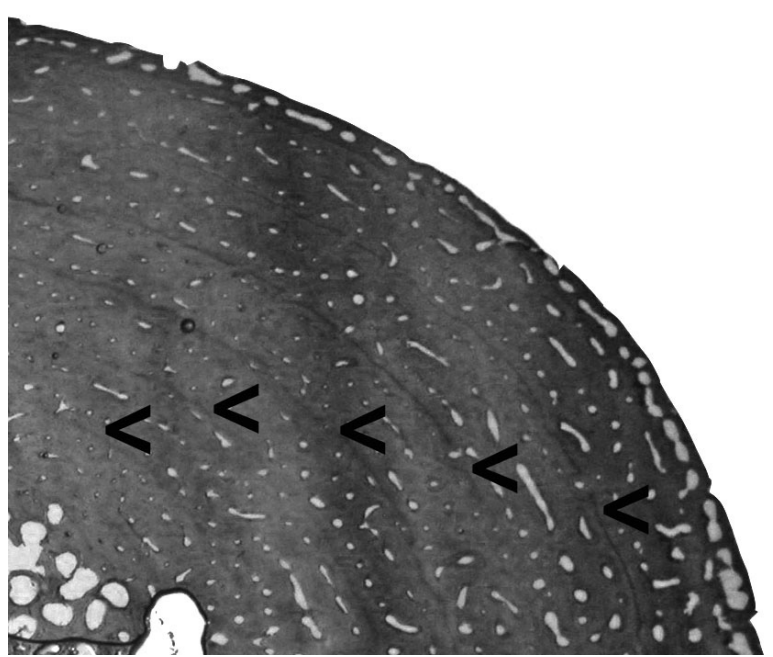

FIG. 1. - Image of bone section. Arrows show the lines of arrested growth (LAGs).

on the diameter of the section and the structure of the bone. After decalcification, bone sections were rinsed in water overnight, embedded in Killik compound (Bio-Optica) and frozen. Transverse sections (20-24 $\mu \mathrm{m}$ thick) were cut on a cryostat (Leica) and collected on microscope slides covered by glycerin film. Sections were stained with Mayer's hematoxylin and observed with a stereomicroscope. Digital images of selected sections were captured using a digital camera connected to the microscope and analyzed with the image analysis software TpsDig2 (F.J. Rohlf, Ecology and Evolution, SUNY at Stony Brook) to identify, count and measure the lines of arrested growth (LAGs), which delimit the marks of skeletal growth (MSGs) (Fig. 1). Skeletochronology is based on the assumption that the deposition of MSGs and LAGs follows an annual cycle as confirmed by several studies on loggerhead turtles in the Atlantic (Klinger and Musick, 1992; Coles et al., 2001; Bjorndal et al., 2003; Snover and Hohn, 2004). Twenty-two samples were conservatively excluded from the analysis either because of damage during the sectioning or because the LAGs were anomalous and could not be clearly identified (see Zug et al., 1986; Snover and Hohn, 2004; Avens et al., 2009) or because they were missing. Thus, complete data were available for a total of 33 turtles.

The thickness of each MSG was calculated as the difference between the diameters (long axis) of the corresponding pair of LAGs.

We also measured the humerus diameter and CCL of a hatchling loggerhead turtle found dead at an Italian nesting site in 1991 and preserved in ethanol.

\section{Data analysis}

From the above data, growth patterns were estimated using two different approaches: (a) the growth rate (GR) method and (b) the age-at-size (AS) method.
In the GR method, two LAGs are considered for each turtle and the size (CCL) of the turtle at the time these LAGs were deposited is calculated by a backcalculation (Francis, 1990; Snover et al., 2007). In this way the time interval between the two LAGs can be associated with the increment in the turtle's body size during the same time interval, thereby providing a growth rate. According to Snover et al. (2007) the back-calculation equation that best fits the relation between humerus diameter and carapace length of turtles has the following form:

$$
\mathrm{L}_{\mathrm{e}}=\mathrm{L}_{\mathrm{h}}+\mathrm{b}\left(\mathrm{D}-\mathrm{D}_{\mathrm{h}}\right)^{\mathrm{c}}
$$

where $L_{e}$ is the carapace length estimated to correspond to a $L A G$ diameter $(D), L_{h}$ is the carapace length of the hatchling, $\mathrm{D}_{\mathrm{h}}$ is the humerus diameter of the hatchling, $\mathrm{b}$ is the slope of the relationship, and $\mathrm{c}$ is the allometric proportionality coefficient.

The two parameters $\mathrm{b}$ and $\mathrm{c}$ which best fitted the present sample $(n=33)$ were estimated with the nonlinear estimation procedure of the program STATISTICA (StatSoft, Inc.).

Since each turtle can fit the general relation differently, the $L_{e}$ values calculated from the turtle's LAGs with the above equation were adjusted for each turtle as follows (Francis, 1990; Snover et al., 2007):

$$
\mathrm{CCL}_{\mathrm{BC}}=\mathrm{L}_{\mathrm{e}} \cdot \mathrm{L}_{\mathrm{of}} \cdot \mathrm{L}_{\mathrm{ef}}^{-1}
$$

where $\mathrm{CCL}_{\mathrm{BC}}$ is the adjusted carapace length calculated with this back-calculation procedure, $\mathrm{L}_{\mathrm{e}}$ is the carapace length estimated as above, $\mathrm{L}_{\text {of }}$ is the observed final carapace length of the dead turtle, and $\mathrm{L}_{\mathrm{ef}}$ is the carapace length estimated as above from the observed final humerus diameter of the dead turtle. The difference between $\mathrm{L}_{\mathrm{of}}$ and $\mathrm{L}_{\mathrm{ef}}$ was evaluated with a paired t-test. For each turtle, $\mathrm{CCL}_{\mathrm{BC}}$ was calculated from the most internal and the most external visible LAG and the time interval in years was considered equal to MSGs. These data were analyzed with Faben's method for the analysis of growth increment data in the programme FiSAT II (Gayanilo et al., 2005), in order to estimate the von Bertalanffy (1938) growth function (VBGF) parameters $\mathrm{L}_{\infty}$ (mean asymptotic carapace length) and $\mathrm{k}$ (growth coefficient), assuming that this function can describe the growth in the observed size range (see Casale et al., 2009).

In the AS method, the age at the size of death of each turtle is considered equal to the total number of MSGs. However, due to bone resorption and redeposition, earlier MSGs are lost during growth and the number of these lost MSGs must be estimated (Zug et al., 1986). This was carried out with the correction factor method (Parham and Zug, 1997), which consists in extrapolating the number of lost MSGs from the average width of the observed MSGs. These estimated lost MSGs are then added to the observed MSGs in order to provide the total number of MSGs, i.e. the age in years at death. This is summarized by the following equation: 


$$
\text { Age }=\mathrm{MSG}_{\mathrm{v}}+\left(\mathrm{D}_{\text {Lag int }}-\mathrm{D}_{\mathrm{h}}\right) \mathrm{C}
$$

where $\mathrm{MSG}_{\mathrm{v}}$ is the number of visible MSGs, $\mathrm{D}_{\mathrm{Lag}}$ int is the diameter of the most internal LAG (absorption core), $D_{h}$ is the diameter of the humerus of the hatchling, and $\mathrm{C}$ is the correction factor. The difference in diameters of the internal LAG and the hatchling humerus represents the resorbed part of the bone. The correction factor $(\mathrm{C})$ is the reciprocal of the average width of visible MSGs. Since larger turtles, especially after sexual maturation, have a slower growth rate (Carr and Goodman, 1970) and deposit smaller MSGs (Parham and Zug, 1997), it is preferable to use an average MSG calculated from smaller turtles in order to reduce the risk of using a low average MSG and of an associated overestimation of the number of lost MSGs (Parham and Zug, 1997). Thus, the average MSG was only calculated from 68 MSGs in 26 turtles $<60 \mathrm{~cm}$ $\mathrm{CCL}$, which is the minimum size recorded for a nesting female in the Mediterranean (Margaritoulis et al., 2003), with resorption core diameters $<20 \mathrm{~mm}$.

The age at size of death data for each turtle were used to estimate the VBGF parameters $\mathrm{L}_{\infty}$ (mean asymptotic carapace length) and $\mathrm{k}$ (growth coefficient) with the nonlinear estimation procedure of the program STATISTICA (StatSoft, Inc.).

For both methods (GR and AS) the parameter k was also estimated by fixing $\mathrm{L}_{\infty}$ at $99 \mathrm{~cm} \mathrm{CCL}$, the maximum CCL recorded in the Mediterranean (Margaritoulis et al., 2003).

The VBGF in the following form was used to estimate the time required by turtles to grow to the size of sexual maturity in the Mediterranean:

$$
\mathrm{L}_{\mathrm{t}}=\mathrm{L}_{\infty}-\left(\mathrm{L}_{\infty}-\mathrm{L}_{0}\right) \mathrm{e}^{(-\mathrm{kt})}
$$

where $\mathrm{L}_{\mathrm{t}}$ is the carapace length at age $\mathrm{t}, \mathrm{L}_{\infty}$ is the mean asymptotic carapace length, $\mathrm{L}_{0}$ is the initial carapace length, and $\mathrm{k}$ is the growth coefficient.

\section{RESULTS}

The CCL and the humerus diameter of the hatchling were $3.9 \mathrm{~cm}$ and $1.8 \mathrm{~mm}$ respectively.

In the animals for which both right and left humeri were collected $(n=6)$ the same number of LAGs were observed and the diameters of the corresponding LAGs did not differ (paired t-test; $\mathrm{t}=-1.53 ; \mathrm{p}=0.13 ; \mathrm{n}=30$ ).

No correlation was observed between MSG width and the corresponding LAG diameter $\left(\mathrm{r}^{2}=0.00 ; \mathrm{t}=0.24\right.$; $\mathrm{p}=0.81 ; \mathrm{n}=89$ ) (Fig. 2), which supports the use of the correction factor protocol for extrapolating resorbed MSGs from the visible ones. Great variability and no general pattern were observed in the width in consecutive MSGs at an individual level (Fig. 3).

The parameters of Equation 1 were estimated as $\mathrm{b}=3.301$ and $\mathrm{c}=0.954(\mathrm{r}=0.968)$. The mean difference of estimated CCL $\left(\mathrm{L}_{\mathrm{ef}}\right)$ and real CCL values $\left(\mathrm{L}_{\mathrm{of}}\right)$ at death was $0.06 \mathrm{~cm}(\mathrm{SD}=3.54 ; \mathrm{n}=33)$.

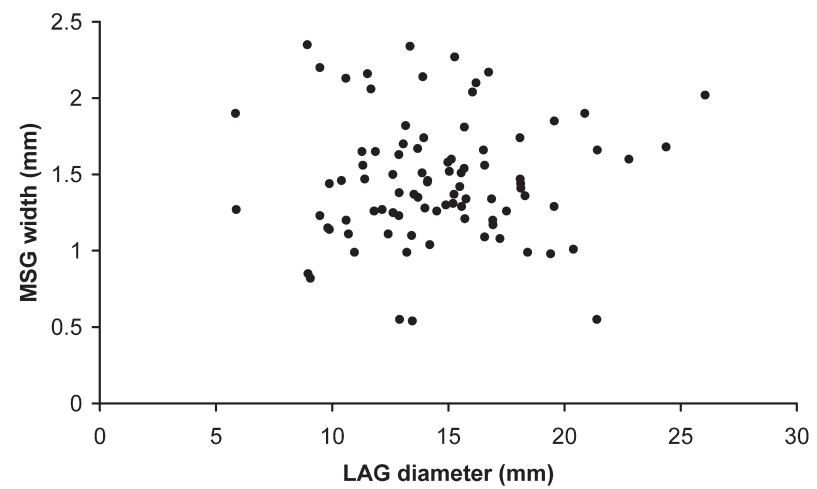

FIG. 2. - Width of marks of skeletal growth (MSG) in relation to the corresponding internal lines of arrested growth (LAG) $(n=89)$.

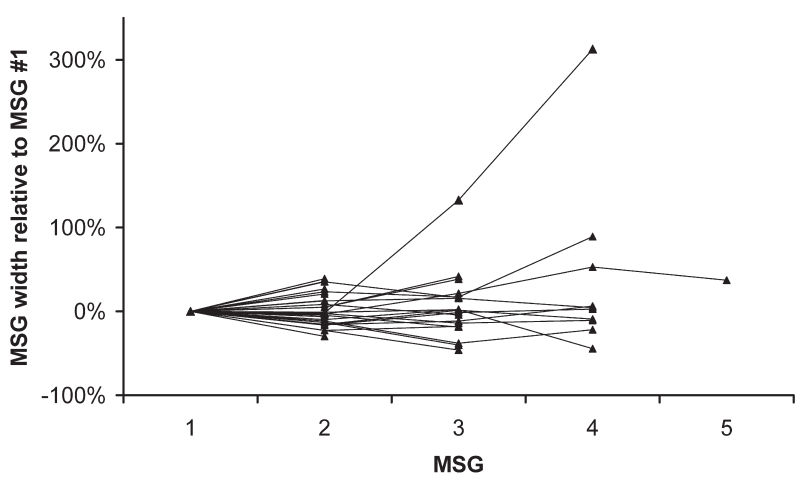

FIG. 3. - Change of width of marks of skeletal growth (MSG) in 28 individual turtles with at least two observed MSGs, expressed as change (\%) from the most internal MSG (\#1).

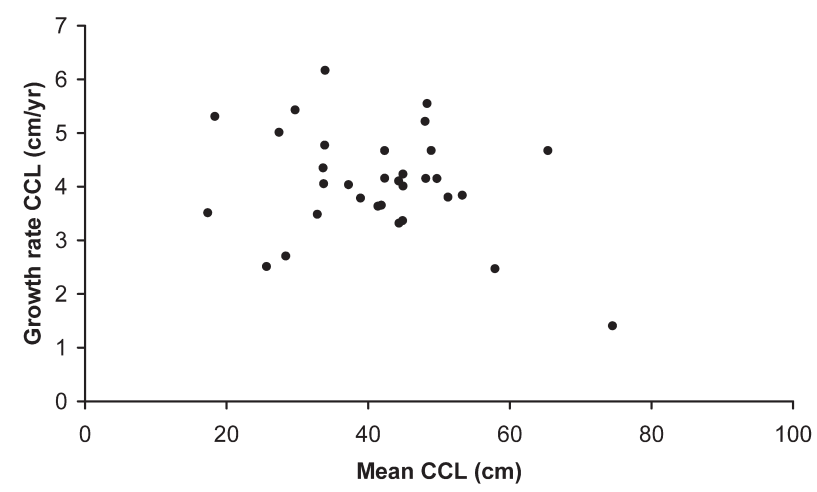

FIG. 4. - Growth rates and mean size curved carapace length (CCL) of 32 loggerhead turtles in which CCLs were back-calculated from the diameter of lines of arrested growth (LAG).

$\mathrm{CCL}_{\mathrm{BC}}$ values calculated from the most internal and external LAG of each turtle ranged from 15.6 to 78.7 $\mathrm{cm}$. The median $\mathrm{CCL}_{\mathrm{BC}}$ for each turtle ranged from 17.3 to $74.5 \mathrm{~cm}(\mathrm{n}=32)$ and the corresponding growth rates ranged from 1.41 to $6.17 \mathrm{~cm} \mathrm{yr}^{-1}$ (Fig. 4).

The age at death estimated with the AS method ranged from 3.7 to 35.7 years (mean: 11; SD: 5.5; $\mathrm{n}=33$ ) (Fig. 5).

The estimated VBGF parameters $\mathrm{k}$ (growth coefficient) and $\mathrm{L}_{\infty}$ (mean asymptotic carapace length) (Eq. 


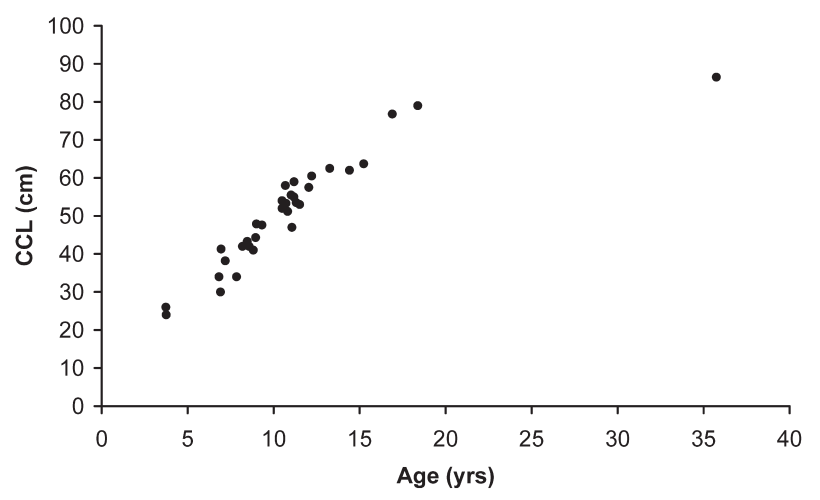

FIG. 5. - Age of 33 loggerhead turtles estimated with the age at size (AS) method.

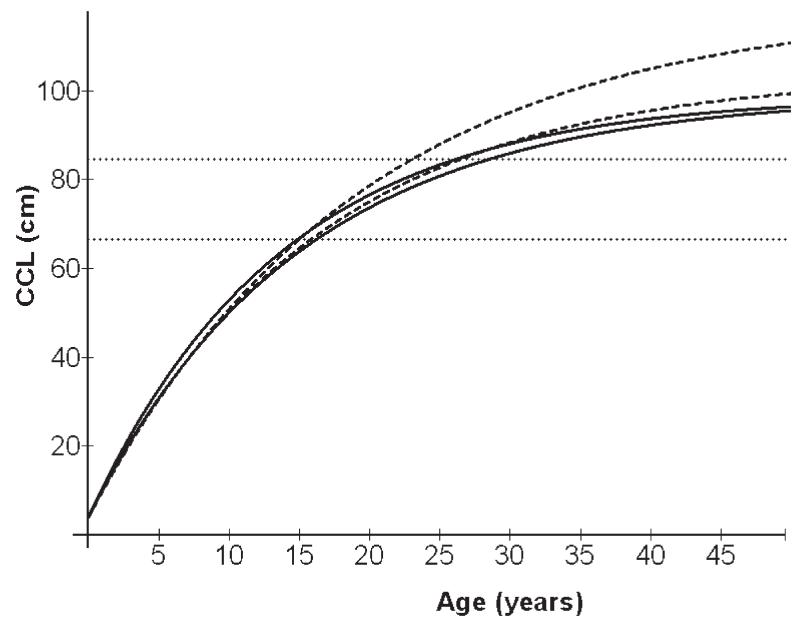

FIG. 6. - The von Bertalanffy growth functions as described in Table 1 , with $\mathrm{L}_{\infty}$ estimated (dashed lines) or fixed at $99 \mathrm{~cm}$ CCL (solid lines). In both cases, the upper curves were obtained with the growth rate (GR) method and the lower curves were obtained with the age at size (AS) method. Horizontal dashed lines show the range of mean curved carapace lengths (CCL) of Mediterranean nesting females (Margaritoulis et al., 2003): 66.5 and $84.7 \mathrm{~cm} \mathrm{CCL}$.

4) resulting from the GR and AS methods are shown in Table 1, and the corresponding VBGFs are shown in Figure 6.

The ages estimated with these VBGFs at 66.5 to $84.7 \mathrm{~cm} \mathrm{CCL}$ (range of means of nesting females observed in different nesting seasons and sites in the Mediterranean; Margaritoulis et al., 2003) ranged between 14.9 and 26.3 years with the GR method and between 15.9 and 28.5 years with the AS method.

TABLE 1. - Von Bertalanffy growth function (VBGF) parameters $k$ (growth coefficient) and $\mathrm{L}_{\infty}$ (mean asymptotic carapace length) resulting from the growth rate (GR) and the age at size (AS) methods and the ages calculated from these VBGFs for the range of mean curved carapace lengths (CCL) of Mediterranean nesting females (Margaritoulis et al., 2003). Values are also provided for $\mathrm{L}_{\infty}$ fixed at the maximum CCL recorded in the Mediterranean.

\begin{tabular}{lcccc}
\hline & \multicolumn{2}{c}{ AS Method } & \multicolumn{2}{c}{ GR Method } \\
\hline $\mathrm{L}_{\infty}(\mathrm{cm})$ & 103.88 & 99 (fixed) & 119.32 & 99 (fixed) \\
$\mathrm{k}\left(\mathrm{yr}^{-1}\right)$ & 0.062 & 0.066 & 0.052 & 0.072 \\
Age at $66.5 \mathrm{~cm}(\mathrm{yrs})$ & 15.9 & 16.2 & 15.0 & 14.9 \\
Age at $84.7 \mathrm{~cm}(\mathrm{yrs})$ & 26.6 & 28.5 & 23.2 & 26.3 \\
\hline
\end{tabular}

\section{DISCUSSION}

\section{Growth rate}

The results show that growth rates vary greatly among individuals (Fig. 4), thus confirming the variability observed with the previously employed method of capture-mark-recapture (Casale et al., 2009). Interindividual growth rate variability can be attributed to several factors. First, growth rates might have a genetic basis and vary among populations. The Mediterranean Sea is known to be frequented by turtles, especially small juveniles, belonging to the Atlantic populations (Laurent et al., 1998; Carreras et al., 2006; Casale et al., 2008 b), which may be a source of variability. Another possible factor is spatial variability (e.g. food availability). In fact, a variety of different habitats can be found within a relatively short distance in the Mediterranean, and turtles, especially small ones, have been shown to move among distant areas (Casale et al., 2007). Therefore, individuals frequenting, by chance or preference, areas with different trophic resources would be expected to show different growth rates (e.g. Diez and van Dam, 2002; Balazs and Chaloupka, 2004).

Unlike other approaches, schelotochronology can provide information on time-related growth rates in the same individual. Therefore, in addition to interindividual variability, the present results also provide evidence of intra-individual growth rate variability during the turtle's lifetime.

Turtles appear to have experienced alternating periods of fast and slow growth without any evident general pattern (Fig. 3), which is also indicated by there not being a general relation between growth rates (MSG width) and animal size (LAG diameter) (Fig. 2).

This great variability suggests that turtles often move to different areas or habitats with different thermal or trophic characteristics. The Mediterranean Sea is a small basin if compared with oceans, and it features both neritic and oceanic areas within short distances. These oceanographic features allow loggerhead turtles to exploit different trophic resources opportunistically without necessarily showing distinct ecological stages (oceanic and neritic). Even in oceans there is evidence of more complex patterns (McClellan and Read, 2007), and diet analyses indicate that in the Mediterranean turtles feed opportunistically (Casale $e t$ al., 2008a). Accordingly, capture-mark-recapture and satellite tracking show that turtles move widely among different foraging areas (Margaritoulis et al., 2003; Casale et al., 2007; Revelles et al., 2007). The lack of a decreasing growth rate pattern (Figs. 2 and 3 ) is probably due to: (i) the size range of the turtles considered in this study, the majority of which are smaller than $60 \mathrm{~cm}$ CCL and so much smaller than the size at maturity (Margaritoulis et al., 2003; Casale et al., 2005), when growth is expected to slow significantly (Carr and Goodman, 1970); and (ii) the intrinsic limitation of skelotochronology, which has difficulties in analyz- 
ing very narrow periostal growth marks typical of large turtles (Zug et al., 1986). The linear relation between age and size observed in almost all individuals, except the largest one (Fig. 5), suggests that a strong reduction in growth rate does not occur before the turtle reaches a size between 80 and $90 \mathrm{~cm} \mathrm{CCL}$, which corresponds to the size at sexual maturation in the Mediterranean (Margaritoulis et al., 2003; Casale et al., 2005). However, more individuals of this size class should be analyzed to confirm this. Capture-mark-recapture studies in the Mediterranean on nesting females (Broderick et al., 2003) and on turtles found at sea (Casale et al., 2009) reported growth rates higher than $1 \mathrm{~cm} \mathrm{yr}^{-1}$ in some turtles larger than $70 \mathrm{~cm} \mathrm{CCL}$, which is compatible with the present findings (Fig. 4).

The growth rates observed in this study (Fig. 4) are similar to those from the Atlantic: Bjorndal et al. (2000) reported comparable growth rates of 10 juvenile specimens with mean CCL in the range between 30 and $80 \mathrm{~cm}$.

\section{Age at sexual maturity}

Mediterranean loggerhead turtles are much smaller than any other population (Dodd, 1988; Tiwari and Bjorndal, 2000), with individual nesting females ranging between 60 and $99 \mathrm{~cm} \mathrm{CCL}$, while average sizes in different nesting sites range from 66.5 to $84.7 \mathrm{~cm} \mathrm{CCL}$ (Margaritoulis et al., 2003). Thus, the relation between the size and the age at maturity cannot be assumed to be the same as in other populations because Mediterranean loggerhead turtles could have either a lower growth rate with similar age at maturity, or a shorter maturation period with a similar growth rate. Moreover, the age at maturity may have important consequences for our knowledge of the dynamics of the Mediterranean population and of its capacity to respond to the relevant human impact in the area, because the longer the maturation time, the slower the population growth (e.g. see Heppell et al., 2003a).

The present results indicate that turtles would take 14.9 to 28.5 years to reach the mean size of Mediterranean nesting females (66.5 to $84.7 \mathrm{~cm}$ CCL; Margaritoulis et al., 2003).

However, the average age at maturity of Mediterranean loggerhead turtles is probably in the upper part of this range, since the smallest females are only from Cyprus, while the other nesting areas with more abundant populations (Greece, Turkey, Libya) have larger nesting females (Margaritoulis et al., 2003). In Greece, mean sizes are above $81.6 \mathrm{~cm}$ CCL, while in Turkey and Libya they are above $76 \mathrm{~cm} \mathrm{CCL} \mathrm{(Margaritoulis}$ et al., 2003), corresponding to an age over 23.6 and 19.7 years respectively according to the VBGFs with $\mathrm{L} \infty$ fixed at $99 \mathrm{~cm} \mathrm{CCL}$ (Fig. 6).

The previous approach, based on capture-markrecapture data, estimated the range at maturity as 16 to 28 years (Casale et al., 2009), which is very close to the present estimation of 14.9 to 28.5 years. The similar values obtained with two skelotochrological approaches (GR and AS, present study) and with a capture-mark-recapture approach (i) reinforce each other and represent a strong indication of the reliability of these values, and (ii) represent a validation of all these methods.

\section{ACKNOWLEDGEMENTS}

We are greatly indebted to the many fishermen who collaborated in this study and to the many volunteers who supported it indirectly by helping us during the activities carried out at the WWF-Italy's Sea Turtle Rescue Centre in Lampedusa.

\section{REFERENCES}

Avens, L. and L.R. Goshe. - 2007. Comparative skeletochronological analysis of Kemp's ridley (Lepidochelys kempii) and loggerhead (Caretta caretta) humeri and scleral ossicles. Mar. Biol., 152: 1309-1317.

Avens, L., J.C. Taylor, L.R. Goshe, T.T. Jones and M. Hastings. 2009. Use of skeletochronological analysis to estimate the age of leatherback sea turtles Dermochelys coriacea in the western North Atlantic. Endang. Species Res., 8: 165-177.

Balazs, G.H. and M. Chaloupka. - 2004. Thirty-year recovery trend in the once depleted Hawaiian green sea turtle stock. Biol. Conserv., 117: 491-498.

Bjorndal, K.A. and A.B. Bolten. - 1988. Growth rates of juvenile loggerheads, Caretta caretta, in the southern Bahamas. J. Herpetol., 22: 480-482.

Bjorndal, K.A., A.B. Bolten and H.R. Martins. - 2000. Somatic growth model of juvenile loggerhead sea turtles Caretta caretta: duration of pelagic stage. Mar. Ecol. Prog. Ser., 202: 265-272.

Bjorndal, K.A., A.B. Bolten, T. Dellinger, C. Delgado and H.R. Martins. - 2003. Compensatory growth in oceanic loggerhead sea turtles: Response to a stochastic environment. Ecology, 84: $1237-1249$.

Bolten, A.B. - 1999. Techniques for measuring sea turtles. In: K.L. Eckert, K.A. Bjorndal, F.A. Abreu-Grobois and M. Donnelly (eds.), Research and Management Techniques for the Conservation of Sea Turtles, pp. 110-114. IUCN/SSC Marine Turtle Specialist Group.

Broderick, A.C., F. Glen, B.J. Godley and G.C. Hays. - 2003. Variation in reproductive output of marine turtles. J. Exp. Mar. Biol. Ecol., 288: 95-109.

Carr, A. and D. Goodman. - 1970. Ecologic implications of size and growth in Chelonia. Copeia, 1970: 783-786.

Carreras, C., S. Pont, F. Maffucci, M. Pascual, A. Barcelo, F. Bentivegna, L. Cardona, F. Alegre, M. SanFelix, G. Fernandez and A. Aguilar. - 2006. Genetic structuring of immature loggerhead sea turtles (Caretta caretta) in the Mediterranean Sea reflects water circulation patterns. Mar. Biol., 149: 1269-1279.

Casale, P. - 2011. Sea turtle by-catch in the Mediterranean. Fish Fish., DOI: 10.1111/j.1467-2979.2010.00394.x

Casale, P., D. Freggi, R. Basso and R. Argano. - 2005. Size at male maturity, sexing methods and adult sex ratio in loggerhead turtles (Caretta caretta) from Italian waters investigated through tail measurements. Herpetolog. J., 15: 145-148.

Casale, P., D. Freggi, R. Basso, C. Vallini and R. Argano. - 2007. A model of area fidelity, nomadism, and distribution patterns of loggerhead sea turtles (Caretta caretta) in the Mediterranean Sea. Mar. Biol., 152: 1039-1049.

Casale, P., G. Abbate, D. Freggi, N. Conte, M. Oliverio and R. Argano. - 2008a. Foraging ecology of loggerhead sea turtles Caretta caretta in the central Mediterranean Sea: evidence for a relaxed life history model. Mar. Ecol. Prog. Ser., 372: 265-276.

Casale, P., D. Freggi, P. Gratton, R. Argano and M. Oliverio. 2008b. Mitochondrial DNA reveals regional and interregional importance of the central Mediterranean African shelf for loggerhead sea turtles (Caretta caretta). Sci. Mar., 72: 541-548. 
Casale, P., A.D. Mazaris, D. Freggi, C. Vallini and R. Argano. 2009. Growth rates and age at adult size of loggerhead sea turtles (Caretta caretta) in the Mediterranean Sea, estimated through capture-mark-recapture records. Sci. Mar., 73: 589-595.

Coles, W.C., J.A. Musick and L.A. Williamson. - 2001. Skeletochronology validation from an adult loggerhead (Caretta caretta). Copeia, 2001: 240-242.

Diez, C.E. and R.P. van Dam. - 2002. Habitat effect on hawksbill turtle growth rates on feeding grounds at Mona and Monito Islands, Puerto Rico. Mar. Ecol. Prog. Ser., 234: 301-309.

Dodd, C.K.J. - 1988. Synopsis of the biological data on the loggerhead sea turtle Caretta caretta (Linnaeus 1758). U.S. Fish Wildl. Serv., Biol. Rep. 88(14).

Francis, R. - 1990. Back-calculation of fish length: a critical review. J. Fish Biol., 36: 883-902.

Gayanilo, F.C.J., P. Sparre and D. Pauly - 2005. FAO-ICLARM Stock Assessment Tools II (FiSAT II). Revised version. User's guide. FAO Computerized Information Series (Fisheries). No. 8 , Revised version. FAO, 168.

Hamann, M., M.H. Godfrey, J.A. Seminoff, K. Arthur, P.C.R. Barata, K.A. Bjorndal, A.B. Bolten, A.C. Broderick, L.M. Campbell, C. Carreras, P. Casale, M. Chaloupka, S.K.F. Chan, M.S. Coyne, L.B. Crowder, C.E. Diez, P.H. Dutton, S.P. Epperly, N.N. FitzSimmons, A. Formia, M. Girondot, G.C. Hays, C. IJiunn, Y. Kaska, R. Lewison, J.A. Mortimer, W.J. Nichols, R.D. Reina, K. Shanker, J.R. Spotila, J. Tomás, B.P. Wallace, T.M. Work, J. Zbinden and B.J. Godley. - 2010. Global research priorities for sea turtles: informing management and conservation in the $21 \mathrm{st}$ century. Endang. Species Res., 11: 245-269.

Heppell, S.S., L.B. Crowder, D.T. Crouse, S.P. Epperly and N.B. Frazer. - 2003a. Population models for Atlantic loggerheads: past, present, and future. In: A.B. Bolten and B.E. Witherington (eds.), Loggerhead Sea Turtles, pp. 255-273. Smithsonian Books, Washington, D.C. .

Heppell, S.S., M.L. Snover and L.B. Crowder. - 2003b. Sea turtle population ecology. In: P.L. Lutz, J.A. Musick and J. Wyneken (eds.), The Biology of Sea Turtles. Volume II. , pp. 275-306. CRC Marine Biology Series, CRC Press, Inc., Boca Raton, London, New York, Washington D.C.

Klinger, R.C. and J.A. Musick. - 1992. Annular growth layers in juvenile loggerhead turtles (Caretta caretta). Bull. Mar. Sci., 51: 224-230

Laurent, L., P. Casale, M.N. Bradai, B.J. Godley, G. Gerosa, A.C. Broderick, W. Schroth, B. Schierwater, A.M. Levy, D. Freggi, E.M. Abd El-Mawla, D.A. Hadoud, H.E. Gomati, M. Domingo, M. Hadjichristophorou, L. Kornaraky, F. Demirayak and C. Gautier. - 1998. Molecular resolution of marine turtle stock composition in fishery bycatch: a case study in the Mediterranean. Mol. Ecol., 7: 1529-1542.

Lutcavage, M.E., P. Plotkin, B.E. Witherington and P.L. Lutz. 1997. Human impacts on sea turtle survival. In: P.L. Lutz and J.A. Musick (eds.), The Biology of Sea Turtles, pp. 387-409. CRC Press, Inc., Boca Raton, Florida.

Margaritoulis, D., R. Argano, I. Baran, F. Bentivegna, M.N. Bradai, J.A. Caminas, P. Casale, G. De Metrio, A. Demetropoulos, G. Gerosa, B. Godley, J. Houghton, L. Laurent and B. Lazar. 2003. Loggerhead turtles in the Mediterranean Sea: present knowledge and conservation perspectives. In: A.B. Bolten and B. Witherington (eds.), Biology and Conservation of Loggerhead Sea Turtles, pp. 175-198. Smithsonian Institution Press.

Mazaris, A.D., O. Fiksen and Y.G. Matsinos. - 2005. Using an individual-based model for assessment of sea turtle population viability. Popul. Ecol., 47: 179-191.

McClellan, C.M. and A.J. Read. - 2007. Complexity and variation in loggerhead sea turtle life history. Biol. Lett., 3: 592-594.

Parham, J.F. and G.R. Zug. - 1997. Age and growth of loggerhead sea turtles (Caretta caretta) of coastal Georgia: An assessment of skeletochronological age-estimates. Bull. Mar. Sci., 61: 287-304

Revelles, M., L. Cardona, A. Aguilar, M. San Felix and G. Fernandez. - 2007. Habitat use by immature loggerhead sea turtles in the Algerian Basin (western Mediterranean): swimming behaviour, seasonality and dispersal pattern. Mar. Biol., 151: $1501-1515$.

Snover, M.L., L. Avens and A.A. Hohn. - 2007. Back-calculating length from skeletal growth marks in loggerhead sea turtles Caretta caretta. Endang. Species Res., 3: 95-104.

Snover, M.L. and A.A. Hohn. - 2004. Validation and interpretation of annual skeletal marks in loggerhead (Caretta caretta) and Kemp's ridley (Lepidochelys kempii) sea turtles. Fish. Bull., 102: 682-692.

Tiwari, M. and K.A. Bjorndal. - 2000. Variation in morphology and reproduction in loggerheads, Caretta caretta, nesting in the United States, Brazil, and Greece. Herpetologica, 56: 343-356.

Von Bertalanffy, L. - 1938. A quantitative theory of organic growth (inquiries on growth laws). Human Biol., 10: 181-213.

Zug, G.R., A.H. Wynn and C. Ruckdeschel. - 1986. Age determination of loggerhead sea turtles, Caretta caretta, by incremental growth marks in the skeleton. Smithson. Contrib. Zool., 427: $1-34$.

Scient. ed.: B. Morales-Nin.

Received March, 9, 2010. Accepted July 12, 2010.

Published online January 11, 2011 